\title{
Population-based Study of 24 Autoimmune Diseases Carried Out in a Brazilian Microregion
}

\author{
Dilceu Silveira Tolentino Júnior ${ }^{1,{ }^{*}}$, Carla Meireles de Oliveira ${ }^{2}$, Eliseu Miranda de Assis ${ }^{3}$ \\ ${ }^{1}$ Department of Epidemiological Surveillance, Municipal Health Secretariat, Machacalis, Minas Gerais, Brazil \\ ${ }^{2}$ Department of Epidemiological Surveillance, Municipal Health Secretariat, Crisólita, Minas Gerais, Brazil \\ ${ }^{3}$ Academic Department, Federal Institute of Bahia, Eunápolis, Bahia, Brazil
}

\section{ARTICLE INFO}

Article History

Received 03 June 2019

Accepted 18 September 2019

\section{Keywords}

Autoimmune diseases

epidemiological survey

prevalence

incidence

sociodemographic profile

\begin{abstract}
In Brazil, epidemiological data on autoimmune diseases are scarce due to the lack of a specific policy of attention to this group of diseases. This study aimed to estimate the general and relative prevalence of the diseases presented, as well as to know the sociodemographic profile of the identified cases. This cross-sectional study was conducted with an epidemiological survey of patients with confirmed diagnosis of autoimmune diseases from primary health care in the Aguas Formosas microregion, Minas Gerais, Brazil. We have included all new and old cases found of individuals of both sexes and all ages, including those who died and emigrated during this period. A total of 407 carriers and 24 different autoimmune diseases were identified. The prevalence of autoimmune diseases in this region was 673.6 cases per 100,000 inhabitants [95\% confidence interval (CI): 609.8-742.4]. Highest prevalence was identified for Hashimoto's thyroiditis 140.6 cases per 100,000 (95\% CI: 112.4-173.9), followed by vitiligo 132.4 cases per 100,000 (95\% CI: 105.0-164.8), and rheumatoid arthritis 105.9 cases per 100,000 (95\% CI: 81.6-135.3). The sex ratio was higher in females (69\%), the most affected age group was over 60 years $(30.5 \%)$, with greater predominance in the urban area $(81.3 \%)$. Our data showed the general and relative prevalence of the identified diseases, allowing to know the sociodemographic profile of the identified cases and the epidemiological trend of these morbidities in a low-income Brazilian region.
\end{abstract}

(C) 2019 Atlantis Press International B.V

This is an open access article distributed under the CC BY-NC 4.0 license (http://creativecommons.org/licenses/by-nc/4.0/).

\section{INTRODUCTION}

Autoimmune Diseases (ADs) are a complex and heterogeneous group of diseases characterized by the loss of immunological tolerance to their own antigens and consequent tissue destruction by autoantibodies [1]. Although there are approximately $80 \mathrm{AD}$ types and at least 40 additional diseases with autoimmune basis, many are considered relatively rare. They account for a cumulative overall prevalence of 3-5\% of the world population and their effects on morbidity and mortality are quite high, representing a serious global public health problem [2].

Several studies [3-6] on the prevalence and incidence of ADs have been conducted in the past 30 years. One of these concluded that the average annual percentage of the prevalence of $11 \mathrm{ADs}$ increased worldwide, reaching a range of $7.9-12.5 \%$. It was concluded that the highest annual increase was observed in rheumatic diseases, followed by endocrinological, gastrointestinal, and neurological diseases [6].

There is a lack of current prevalence data from different areas of Europe and North America for many autoimmune disorders [7]. Few epidemiological studies estimating the prevalence of ADs were conducted in Latin America, especially in Brazil [8]. Of course, more studies are needed to know the general and relative

"Corresponding author. Postal Address: Institute of Science, Engineering and Technology, Federal University of the Jequitinhonha and Mucuri Valleys, Teófilo Otoni, Minas Gerais, Brazil, Email: dilceujunior@bol.com.br

Data availability statement: The data that support the findings of this study are available from the corresponding author (DSTJ), upon reasonable request. prevalence rates of ADs in all regions of Brazil, even more considering that epidemiological studies point to an increase in their prevalence in developing countries [9].

In Minas Gerais state, the prevalence of these diseases is unknown [10]. Even with insufficient statistical data, it is believed that there is a significant increase in the prevalence of ADs throughout the country [10]. Among the factors that explain the insufficiency of these data are the difficulties in epidemiological, clinical, and therapeutic analyzes, as well as the lack of preparation of some health professionals, requiring a joint effort of the medical professionals and other researchers in the search, discussion, and dissemination of results on the etiology, specific therapeutics, and reliable epidemiological studies on these nosologies [11].

In this sense, the present study is relevant because this is the first survey carried out in this region and it estimated the respective prevalence of the main autoimmune morbidities that affect the microregion of Águas Formosas, Minas Gerais, Brazil, thereby helping to understand its epidemiological profile to subsidize the adoption of policies in this field.

\section{MATERIALS AND METHODS}

\subsection{Study Design and Scenery}

This is a cross-sectional, descriptive, and exploratory study with a quantitative approach. The research was carried out in 
the microregion of Águas Formosas, located in the northeast of the state of Minas Gerais. The estimated population is 60,413 inhabitants [12], with a geographical area of approximately 4,150,700 $\mathrm{km}^{2}$ [12]; being composed of eight municipalities: Águas Formosas, Bertópolis, Crisólita, Fronteira dos Vales, Machacalis, Pavão, Santa Helena de Minas, and Umburatiba (Table 1). The region is part of the Atlantic forest biome with tropical climate and well-defined seasons. It has riverside population, indigenous population, and their socioeconomic indicators are low [13].

\subsection{Method of Data Collection and Technique used}

The epidemiological survey of ADs was carried out in the 26 primary health care units of the microregion, through the review of medical records and active search conducted from January to December 2016. The results are based on the total number of cases followed, newly discovered or diagnosed. In this work, all prevalent cases, including those who died and/or emigrated, are included in the analyses.

For the general prevalence calculation, the entire set of identified cases was used and, for the calculation of the relative prevalence of each disease, the subsets were multiplied by the constant 100,000 to estimate the punctual prevalence of these diseases in this microregion.

For this, the numerator referred to the number of people diagnosed of all ages registered in the epidemiological survey and the denominator was the population at risk of becoming ill, adopting as based on population estimates [6].

Subsequently, a literature review of the electronic databases was carried out in addition to the inclusion of studies found from these references. The search terms used referred to the prevalence of the 24 diseases identified. The research was approved by the Local Research Ethics Committee.

\subsection{Statistical Analysis}

Prevalence data were expressed as cases per 100,000 inhabitants and 95\% confidence intervals (CIs) were calculated according to the Poisson distribution. The Fisher chi-square test was used to verify the differences in prevalence according to sex. The study used counts, proportions, and rates through the statistical software STATA version 15.0 (StataCorp, College Station, TX, USA).

\section{RESULTS}

\subsection{Population Distribution and Prevalence by Municipality}

Overall, 407 individuals with ADs were identified in the groups evaluated. The estimated prevalence was 673.6 cases per 100,000 inhabitants, distributed among the eight municipalities in the region (Table 2 ).

The municipalities of Machacalis (1106.8 per 100,000 inhabitants), Umburatiba (993.4 per 100,000 inhabitants), and Crisólita (957.6 per 100,000 inhabitants) had the highest prevalence of ADs.

\subsection{Relative Prevalence of Identified Diseases}

The relative prevalences of the 24 ADs identified in the general population of the evaluated region were estimated (Table 3). The study showed the highest prevalences for Hashimoto's thyroiditis, vitiligo, rheumatoid arthritis, psoriasis, Graves' disease, type 1 diabetes mellitus, and systemic lupus erythematosus.

Table 2 Population distribution and prevalence of autoimmune diseases according to municipalities in the Águas Formosas microregion, 2016

\begin{tabular}{lrccc}
\hline & Population & \multicolumn{4}{c}{$\begin{array}{c}\text { Prevalence } \\
\text { Municipality }\end{array}$} & $\begin{array}{l}(\boldsymbol{N})^{*} \\
\text { cases/100,000 } \\
\text { inhabitants }\end{array}$ & 95\% CI \\
\hline Águas Formosas & 19,363 & 89 & 459.6 & $369.1-565.6$ \\
Bertópolis & 4671 & 28 & 599.4 & $398.3-866.4$ \\
Crisólita & 6579 & 63 & 957.6 & $735.8-1225.2$ \\
Fronteira dos Vales & 4743 & 31 & 653.6 & $444.1-927.7$ \\
Machacalis & 7228 & 80 & 1106.8 & $877.6-1377.5$ \\
Pavão & 8724 & 55 & 630.4 & $474.9-820.6$ \\
Santa Helena de Minas & 6387 & 34 & 532.3 & $368.7-743.9$ \\
Umburatiba & 2718 & 27 & 993.4 & $654.6-1445.3$ \\
Total & 60,413 & 407 & 673.6 & $609.8-742.4$ \\
\hline
\end{tabular}

'Brazilian Institute of Geography and Statistics (2016); " Cases identified in the period from January to December 2016; CI, confidence interval.

Table 1 Distribution of the sociodemographic characteristics of the cases identified among small municipalities and their respective general prevalence

\begin{tabular}{|c|c|c|c|c|c|c|}
\hline Municipality & Land area ${ }^{\star *}$ & Population* & Population density ${ }^{\star *}$ & Altitude $e^{\star * *}$ & Latitude & Longitude \\
\hline Águas Formosas & 819,8 & 19,363 & 23,61 & 273 & $-17^{\circ} 04^{\prime} 56^{\prime \prime}$ & $-40^{\circ} 56^{\prime} 09^{\prime \prime}$ \\
\hline Bertópolis & 427 & 4,671 & 10,93 & 278 & $-17^{\circ} 03^{\prime} 47^{\prime \prime}$ & $-40^{\circ} 34^{\prime} 28^{\prime \prime}$ \\
\hline Crisólita & 973 & 6,579 & 6,76 & 282 & $-17^{\circ} 14^{\prime} 14^{\prime \prime}$ & $-40^{\circ} 54^{\prime} 43^{\prime \prime}$ \\
\hline Fronteira dos Vales & 319,8 & 4,743 & 14,83 & 314 & $-16^{\circ} 53^{\prime} 29^{\prime \prime}$ & $-40^{\circ} 55^{\prime} 29^{\prime \prime}$ \\
\hline Machacalis & 330,8 & 7,228 & 21,85 & 285 & $-17^{\circ} 04^{\prime} 38^{\prime \prime}$ & $-40^{\circ} 42^{\prime} 59^{\prime \prime}$ \\
\hline Pavão & 601,4 & 8,724 & 14,50 & 228 & $-17^{\circ} 25^{\prime} 40^{\prime \prime}$ & $-40^{\circ} 59^{\prime} 56^{\prime \prime}$ \\
\hline Santa Helena & 277,9 & 6,387 & 22,98 & 312 & $-16^{\circ} 58^{\prime} 59^{\prime \prime}$ & $-40^{\circ} 41^{\prime} 08^{\prime \prime}$ \\
\hline Umburatiba & 368,5 & 2,718 & 7,37 & 238 & $-17^{\circ} 15^{\prime} 21^{\prime \prime}$ & $-40^{\circ} 34^{\prime} 22^{\prime \prime}$ \\
\hline
\end{tabular}

${ }^{*}$ Population estimate according to the Brazilian Institute of Geography and Statistics (2016). ${ }^{*}$ Per square kilometer. ${ }^{* * *}$ Per square meter. 


\subsection{Distribution of the Sociodemographic Profile of the Sample}

Regarding the absolute frequencies observed, women, people aged 60 years and over, brown skinned, and people from urban areas presented the highest proportions (Table 4).

Table 3 Prevalence of autoimmune diseases in the Águas Formosas microregion, 2016

\begin{tabular}{|c|c|c|c|}
\hline Autoimmune diseases & Cases & $\begin{array}{c}\text { Prevalence } \\
\text { cases/100,000 } \\
\text { inhabitants }\end{array}$ & 95\% CI \\
\hline Hashimoto's thyroiditis & 85 & 140.6 & $112.4-173.9$ \\
\hline Vitiligo & 80 & 132.4 & $105.0-164.8$ \\
\hline Rheumatoid arthritis & 64 & 105.9 & $81.6-135.3$ \\
\hline Psoriasis & 44 & 72.8 & $52.9-97.8$ \\
\hline Graves' disease & 39 & 64.5 & $45.9-88.3$ \\
\hline Type 1 diabetes mellitus & 30 & 49.6 & $33.5-70.9$ \\
\hline Systemic lupus erythematosus & 26 & 43.0 & $28.1-63.1$ \\
\hline Endemic pemphigus foliaceus & 07 & 11.5 & $4.7-23.9$ \\
\hline Lichen planus & 05 & 8.2 & $2.7-19.3$ \\
\hline Idiopathic ulcerative colitis & 05 & 8.2 & $2.7-19.3$ \\
\hline Ankylosing spondylitis & 03 & 4.9 & $1.0-14.5$ \\
\hline Sjögren's syndrome & 03 & 4.9 & $1.0-14.5$ \\
\hline Multiple sclerosis & 02 & 3.3 & $0.0-11.9$ \\
\hline Rheumatic polymyalgia & 02 & 3.3 & $0.0-11.9$ \\
\hline Scleroderma & 02 & 3.3 & $0.0-11.9$ \\
\hline Psoriatic arthritis & 02 & 3.3 & $0.0-11.9$ \\
\hline Crohn's disease & 01 & 1.6 & $0.0-9.2$ \\
\hline Celiac disease & 01 & 1.6 & $0.0-9.2$ \\
\hline Antiphospholipid syndrome & 01 & 1.6 & $0.0-9.2$ \\
\hline Alopecia areata & 01 & 1.6 & $0.0-9.2$ \\
\hline Addison's disease & 01 & 1.6 & $0.0-9.2$ \\
\hline Myasthenia gravis & 01 & 1.6 & $0.0-9.2$ \\
\hline $\begin{array}{l}\text { Immune thrombocytopenic } \\
\text { purpura }\end{array}$ & 01 & 1.6 & $0.0-9.2$ \\
\hline Polymyositis & 01 & 1.6 & $0.0-9.2$ \\
\hline
\end{tabular}

CI, confidence interval.

\subsection{Relative Prevalence According to Sex}

When we evaluated the prevalence of diseases in relation to sex, there was statistical significance $(p<0.001)$ for Hashimoto's thyroiditis, rheumatoid arthritis, Graves' disease, and systemic lupus erythematosus, showing the female sex to be with higher predominance of ADs (Table 5).

\section{DISCUSSION}

When comparing the general prevalence of $\mathrm{ADs}$ in the microregion $(0.67 \%)$ with the worldwide prevalence (3-5\%) [1], it is possible to infer that the microregional estimate is underestimated as the data evaluated were only from the public health network and did not use hospital data and the private health service network, and there may have been some quantitative impairment due to the lack of record of cases by the local health services.

In this study, the municipalities of Machacalis, Umburatiba, and Crisólita presented the highest prevalence. Although there is no specific public policy on ADs in the country and the noninclusion of these morbidities in their national compulsory notification list [3], environmental factors that could determine a greater number of cases were not identified as the counties evaluated share the same microclimate.

Our observations allow comparing the present epidemiological survey with the population-based study of 12 ADs carried out in Sardinia, Italy [14]. It is verified that Hashimoto's thyroiditis was the most prevalent organ-specific disease in both studies. Regarding systemic diseases, vitiligo, rheumatoid arthritis, and psoriasis prevailed in the current study by order, whereas in the Italian study, the order of prevalence was psoriasis, rheumatoid arthritis (also in second position), and ulcerative colitis, demonstrating considerable similarity of prevalence between the studies despite the geographical and demographic differences between these regions.

Table 4 Absolute frequencies and percentages of autoimmune diseases according to sociodemographic characteristics in the Águas Formosas microregion, 2016

\begin{tabular}{|c|c|c|c|c|c|c|c|c|c|}
\hline & \multicolumn{9}{|c|}{ Municipalities of the Águas Formosas microregion } \\
\hline & $\begin{array}{c}\text { Águas } \\
\text { Formosas }\end{array}$ & Machacalis & Crisólita & Pavão & $\begin{array}{c}\text { Santa } \\
\text { Helena }\end{array}$ & $\begin{array}{l}\text { Fronteira } \\
\text { dos Vales }\end{array}$ & Bertópolis & Umburatiba & Total (\%) \\
\hline Cases & 89 & 80 & 63 & 55 & 34 & 31 & 28 & 27 & $407(100)$ \\
\hline \multicolumn{10}{|l|}{ Sex } \\
\hline Male & 30 & 18 & 19 & 29 & 6 & 9 & 6 & 9 & $126(31)$ \\
\hline Female & 59 & 62 & 44 & 26 & 28 & 22 & 22 & 18 & $281(69)$ \\
\hline \multicolumn{10}{|c|}{ Age group (years) } \\
\hline $7-14$ & 3 & 4 & 4 & 5 & 2 & 1 & 1 & 3 & $23(5.7)$ \\
\hline $15-29$ & 7 & 6 & 8 & 4 & 4 & 4 & 5 & 2 & $40(9.8)$ \\
\hline $30-44$ & 20 & 24 & 18 & 12 & 6 & 8 & 4 & 6 & $98(24.1)$ \\
\hline $45-59$ & 28 & 24 & 21 & 17 & 9 & 6 & 8 & 9 & $122(29.9)$ \\
\hline $60+$ & 31 & 22 & 12 & 17 & 13 & 12 & 10 & 7 & $124(30.5)$ \\
\hline \multicolumn{10}{|l|}{ Ethnicity } \\
\hline Black & 5 & 5 & 4 & 2 & 2 & 3 & 3 & 1 & $25(6.1)$ \\
\hline Brown & 60 & 54 & 52 & 44 & 22 & 25 & 21 & 25 & $303(74.4)$ \\
\hline White & 24 & 21 & 7 & 9 & 10 & 3 & 4 & 1 & $79(19.5)$ \\
\hline \multicolumn{10}{|c|}{ Residence zone } \\
\hline Urban & 81 & 75 & 33 & 41 & 29 & 28 & 22 & 22 & $331(81.3)$ \\
\hline Rural & 8 & 5 & 30 & 14 & 5 & 3 & 6 & 5 & $76(18.7)$ \\
\hline
\end{tabular}


Table 5 Prevalence of autoimmune diseases according to sex in the Águas Formosas microregion, 2016

\begin{tabular}{|c|c|c|c|c|c|c|c|}
\hline \multirow[b]{2}{*}{ Autoimmune diseases } & \multicolumn{3}{|c|}{ Women $(N=29,602)$} & \multicolumn{3}{|c|}{$\operatorname{Men}(N=30,811)$} & \multirow[b]{2}{*}{$p$-value ${ }^{\star}$} \\
\hline & Cases & $\begin{array}{l}\text { Prevalence cases/ } \\
100,000 \text { inhabitants }\end{array}$ & $95 \% \mathrm{CI}$ & Cases & $\begin{array}{l}\text { Prevalence cases/ } \\
100,000 \text { inhabitants }\end{array}$ & $95 \% \mathrm{CI}$ & \\
\hline Hashimoto's thyroiditis & 77 & 260.1 & $205.3-325.1$ & 8 & 25.9 & $11.2-51.2$ & $<0.001$ \\
\hline Vitiligo & 43 & 145.3 & $105.1-195.7$ & 37 & 120.1 & $84.6-165.5$ & 0.434 \\
\hline Rheumatoid arthritis & 51 & 172.3 & $128.3-226.5$ & 13 & 42.2 & $22.5-72.2$ & $<0.001$ \\
\hline Psoriasis & 17 & 57.4 & $33.4-91.9$ & 27 & 87.6 & $57.8-127.5$ & 0.177 \\
\hline Graves' disease & 31 & 104.7 & $71.2-148.7$ & 8 & 25.9 & $11.2-51.2$ & $<0.001$ \\
\hline Type 1 diabetes mellitus & 11 & 37.2 & $18.6-66.5$ & 19 & 61.7 & $37.1-96.3$ & 0.203 \\
\hline Systemic lupus erythematosus & 22 & 74.3 & $46.6-112.5$ & 4 & 12.9 & $3.5-33.2$ & $<0.001$ \\
\hline Endemic pemphigus foliaceus & 3 & 10.1 & $2.1-29.6$ & 4 & 12.9 & $3.5-33.2$ & 1.000 \\
\hline Líchen planus & 3 & 10.1 & $2.1-29.6$ & 2 & 6.5 & $0.0-23.5$ & 0.681 \\
\hline Idiopathic ulcerative colitis & 2 & 6.8 & $0.0-24.4$ & 3 & 9.7 & $2.0-28.5$ & 1.000 \\
\hline Ankylosing spondylitis & 2 & 6.8 & $0.0-24.4$ & 1 & 3.3 & $0.0-18.1$ & 0.617 \\
\hline Sjögren's syndrome & 2 & 6.8 & $0.0-24.4$ & 1 & 3.3 & $0.0-18.1$ & 0.617 \\
\hline Multiple sclerosis & 0 & 0.0 & $0.0-12.5$ & 2 & 6.5 & $0.0-23.5$ & 0.500 \\
\hline Rheumatic polymyalgia & 1 & 3.4 & $0.0-18.8$ & 1 & 3.3 & $0.0-18.1$ & 1.000 \\
\hline Scleroderma & 2 & 6.8 & $0.0-24.4$ & 0 & 0.0 & $0.0-11.9$ & 0.240 \\
\hline Psoriatic arthritis & 1 & 3.4 & $0.0-18.8$ & 1 & 3.3 & $0.0-18.1$ & 1.000 \\
\hline Crohn's disease & 0 & 0.0 & $0.0-12.5$ & 1 & 3.3 & $0.0-18.1$ & 1.000 \\
\hline Celiac disease & 0 & 0.0 & $0.0-12.5$ & 1 & 3.3 & $0.0-18.1$ & 1.000 \\
\hline Antiphospholipid syndrome & 1 & 3.4 & $0.0-18.8$ & 0 & 0.0 & $0.0-11.9$ & 0.490 \\
\hline Alopecia areata & 0 & 0.0 & $0.0-12.5$ & 1 & 3.3 & $0.0-18.1$ & 1.000 \\
\hline Addison's disease & 1 & 3.4 & $0.0-18.8$ & 0 & 0.0 & $0.0-11.9$ & 0.490 \\
\hline Myasthenia gravis & 0 & 0.0 & $0.0-12.5$ & 1 & 3.3 & $0.0-18.1$ & 1.000 \\
\hline Immune thrombocytopenic purpura & 1 & 3.4 & $0.0-18.8$ & 0 & 0.0 & $0.0-11.9$ & 0.490 \\
\hline Polymyositis & 1 & 3.4 & $0.0-18.8$ & 0 & 0.0 & $0.0-11.9$ & 0.490 \\
\hline Total & 272 & 918.9 & $812.9-1034.8$ & 135 & 438.2 & $367.4-518.6$ & $<0.001$ \\
\hline
\end{tabular}

'Fisher's Chi-square test was used to verify differences in the prevalence of autoimmune diseases according to sex; CI, confidence interval.

The prevalence of Hashimoto's thyroiditis was lower than in all studies consulted $(300 / 2000$ per 100,000$)$ [15,16], perhaps because the microregion has protective factors such as low latitude and high temperature. The prevalence of vitiligo was higher than the estimate found in the only Brazilian prevalence study $(40$ per 100,000) [17], which may be explained by the ease of clinical diagnosis of the demographic regions of the disease with higher phototypes, such as the microregion. The estimated prevalence of rheumatoid arthritis in the region was lower than all the national studies consulted $(200 / 1000$ per 100,000$)$ $[10,18]$, but with a higher prevalence than the province of Tucumã, Argentina (100 per 100,000) [19]. Surely this microregional index would be higher if the disease were considered to be compulsorily reported, which also suggests that it may not be properly diagnosed [16].

Regarding psoriasis, the results identified the microregion's prevalence to be lower than those of studies conducted in Latin America (3000 per 100,000 in Mexico, 2000 per 100,000 in Venezuela, and 4200 per 100,000 in Paraguay) [20]. This disease has a variable prevalence in different countries from $6.5 \%$ $(6500$ per 100,000$)$ in Germany to a rate of $11.8 \%(11,800$ per $100,000)$ in the city of Kazachye, located in the arctic region of the former Soviet Union [21], perhaps this lower prevalence can be explained by the climate factor of the microregion in relation to other cooler and wetter regions, as protective factors such as hot and dry climate are recognized as variables that can affect its prevalence, and other intervening factors, as a greater propensity of Caucasians to the disease and technical difficulties in the differential diagnosis.
As regards Graves' disease, its prevalence was below the worldwide prevalence rate $(1151.5$ per 100,000$)$ inhabitants [16]. The prevalence in the microregion is possibly lower due to the higher disease propensity in Caucasians. Also, it is believed that the addition of high levels of iodine in drinking water and table salt has an impact on its occurrence and distribution, as in Brazil, iodine content in table salt is officially controlled in commercial products and may be found in lower concentrations, unlike certain countries, such as the United States, where iodized salts have $100 \mathrm{mg}$ per $\mathrm{kg}$ of table salt [22]. In addition, the difficulty of the microregional health system to offer specific laboratory and imaging tests such as scintigraphies for the diagnostic conclusion of the cases could affect the prevalence rate.

As to type 1 diabetes mellitus, the prevalence of microregion is lower than that of worldwide (192 per 100,000) [16], which may be due to the existence of some pertinent problems such as incorrect diagnosis, fragile health promotion actions, underutilization of health information systems, and nonsystematic records $[23,24]$. Technologically more developed regions are more likely to optimize their health systems and improve their indicators to facilitate the planning of preventive and diagnostic actions [25].

Toward systemic lupus erythematosus, the prevalence in the microregion was higher than in Spanish studies (17.5-34.1 per $100,000)[26,27]$ but lower than in the only Brazilian study (98 per 100,000) [10]. Other studies in Latin America [28,29] showed estimates ranging from 50 to 60 per 100,000 , suggesting an increase in the number of cases in tropical and temperate climates in the warmer seasons of the year, probably due to the higher exposure of individuals to ultraviolet light. 
Regarding the prevalence of endemic pemphigus foliaceus in the microregion, it is found to exceed that of the state of Minas Gerais (1.22 per 100,000) [30], which may be due to the rural, riverside, and indigenous population of the microregion that usually has rustic dwellings that favor the circulation of simulids, triatomines, and scimecid bugs, unlike the better housing conditions of the populations of other more developed regions of the state of Minas Gerais [31,32].

Referring to the estimate of lichen planus, it is noted that the prevalence in the microregion is lower than that worldwide. As no national study was found for comparative analysis of its more common clinical form. The exact prevalence of lichen planus is unknown. However, its estimated prevalence ranges from $0.22 \%$ $(220$ per 100,000$)$ to $0.5 \%$ (500 per 100,000$)$ worldwide $[33,34]$. It is suggested that the prevalence of lichen planus in the microregion may be affected by failures due to misdiagnosis, the diversity of clinical presentation, and the asymptomatic nature of the most common subtype that makes the disease an increasingly underdiagnosed health problem $[35,36]$.

With respect to immune ulcerative colitis, its prevalence in the microregion is lower than that of a study conducted in the state of São Paulo, which had a prevalence of 14.81 per 100,000 [37]. Apparently, the prevalence of inflammatory bowel disease in less developed regions such as the microregion is lower than that observed in developed regions, and may also be the result of reduced diagnostic awareness, confusion with infectious causes of diarrhea, or reduced availability of technical resources [38].

Comparing the prevalence of ankylosing spondylitis, the microregion's prevalence is higher than Japan's prevalence (0.48 per $100,000)$ [39], but it is close to other world estimates such as the United States (6.4 per 100,000 in a study in Rochester, Minnesota) [40] and also in studies in northern Europe, such as Finland and Norway (both with 7.3 cases per 100,000) [41,42]; however, in the northeastern region of Greece the prevalence is higher (29.5 per 100,000) [43]. This lower prevalence in the microregion can be explained by geographical and ethnic issues, as the disease is more prone to Caucasians due to the influence of white genetic ancestry, whereas the microregion population is predominantly miscegenated, it is therefore a protective factor that may influence its prevalence $[44,45]$.

Sjögren's syndrome in the microregion was prevalent with a lower level than that found in the only Brazilian study to date conducted in the metropolitan region of Vitória in the state of Espírito Santo (170 per 100,000) [46]. Other studies showed different results that ranged from $0.04 \%(40$ per 100,000$)$ in a study conducted in the United States [47], 0.7\% (700 per 100,000) in China [48], to $3-4 \%(3,000-4,000$ per 100,000$)$ in the United Kingdom [49].

It is possible to verify that the prevalence of multiple sclerosis in the microregion was higher than that in a national study (1.88 per 100,000) [50] but lower than those in other studies conducted in the state of Minas Gerais (12.5/18.1 per 100,000) $[51,52]$ and in the state of São Paulo $(12.5 / 15.54$ per 100,000$)$ $[53,54]$. The microregion may have been influenced by geographical and climatic protection factors, as regions with greater latitude in relation to the equator line tend to have the largest number of cases.
When comparing the prevalence of rheumatic polymyalgia in the microregion with that in the United States (700 per 100,000) [55], a considerable difference was observed. Highest prevalence was reported in rural areas of a Canadian province and greater geographical variation in the Nordic countries, especially Norway, which is contrary to the data in southern European countries such as Spain and Italy where lower values were reported [56,57]. The microregion probably presents a lower prevalence owing to the geographical factor protection along with the difficulty faced in the diagnosis due to the lack of specific tests, as it is relevant for a timely and careful exclusion of other conditions that may mimic it such as late-onset rheumatoid arthritis and malignant neoplasms, which can cause similar symptoms. In this sense, the disease is characterized by wide variations in clinical practice and the available classification criteria are rarely used $[56,58]$.

The scleroderma prevalence rate in the microregion was lower than that found in a Brazilian study $(10.5$ per 100,000) [59] but is higher than that found in a European study $(3.1$ per 100,000$)$ [60], where the rates tend to be lower in northern Europe as is the case in Denmark. Epidemiological studies reveal a higher frequency of this condition in the United States of America (24.2 cases per 100,000) [61] and in southern regions of Europe; the fact that it is a rare disease and the difficulty in diagnosing it make confirmatory cases extremely challenging for the local health system.

In relation to the prevalence of psoriatic arthritis in the microregion, it is concluded that the level found is discrete compared with the worldwide prevalence (20-250 per 100,000) [62]. It is believed that the microregional health system has difficulty with its diagnostic component, given that the use of biomarkers is not available worldwide and there are currently no well-defined criteria and instruments for assessing cases using criteria created for other diseases, increasing the possibility of diagnostic errors $[63,64]$.

As for the prevalence of alopecia areata, Addison's disease, antiphospholipid syndrome, celiac disease, Crohn's disease, myasthenia gravis, polymyositis, and immune thrombocytopenic purpura, all had the same prevalence level in the present study (1.6 per $100,000)$ but were lower than the prevalence studies respectively consulted $(100 / 200,0.45 / 11.7,40 / 50,1,000 / 2,000,5.65,14.2,7.2$, and 11.2 per 100,000$)$ [65-72], suggesting that the small number of cases may be due to the fact that these pathologies are considered rare and the underdiagnosis related to problems with referral flow and counter-referral of users when accessing consultations $[73,74]$.

Among the wide variety of existing ADs, the rarity of occurrence and the difficulty in detecting some of its types in the studied microregion led us to analyze only the most common ones. Although rare individually, as a group they affect a significant percentage of the population, resulting in an important public health problem. Some characteristics inherent to ADs can make the analysis of epidemiological data difficult due to the multiplicity of their clinical forms, long spontaneous remissions, insidious onset that may delay the diagnosis of the disease, and generation of fatal complications preventing its correlation with determining factors [75].

Some studies on the prevalence of ADs were conducted in the country, but individually, being addressed throughout this study. In addition, international statistics indicate that Brazil is still among the countries with the highest incidence of rheumatic fever [76]. 
Regarding Guillain-Barré syndrome, there are no prevalence data in Brazil [77], only studies that indicate an annual incidence of $0.46-0.6$ cases per 100,000 nationwide, and 0.40 for the southeast region of Brazil $[78,79]$. Few epidemiological studies estimating the prevalence of ADs have been conducted in Latin America [80]. Most of the available studies are from North America, Europe, and Asia [81-85].

Some worldwide prevalence estimates have been verified such as Rasmussen's encephalitis with a rate of 0.18 per 100,000 [86]; and incidence rates from several studies were also consulted such as autoimmune hypophysitis with a coefficient of 1 case per 9 million people [87]. For dozens of orphan ADs, such as Cogan's syndrome, there is still no incidence or prevalence data for the limited number of documented patients [88].

Our data show that the higher frequency of ADs affects mainly people of productive age and that the prevalence is proportional to the increase in age, of which most individuals were over 30 years of age according to the literature [89].

A relevant factor that may explain differences in estimates of $\mathrm{AD}$ prevalence is their slow progression of signs and symptoms, making age of onset often unpredictable. In childhood, the most common diseases are type 1 diabetes mellitus, celiac disease, and vitiligo. In young adults, multiple sclerosis, myasthenia gravis, vitiligo, and lupus are the most common. Middle-aged people are more likely to have Sjögren's syndrome, systemic sclerosis, and rheumatoid arthritis. Older people are more likely to have Sjögren's syndrome, Hashimoto's thyroiditis, and myasthenia gravis. Another possibility is that some diseases such as Crohn's disease, myasthenia gravis, psoriasis, and autoimmune thrombocytopenic purpura, have bimodal course with diversified incidence peaks regarding age of onset, generating detection bias and making understanding of the demographic profile of $\mathrm{AD}$ a great challenge for the epidemiology [90].

Regarding ethnicity, browns were a higher percentage of the sample followed by whites, proving that this miscegenation in the microregion can be influenced by Caucasian genetic ancestry that is susceptible to ADs [91]; reinforcing the findings of the study that claims that ADs have a higher incidence in whites and browns than in yellows and blacks [92].

Seminal international study [16] states that geographical and ethnic factors may lead to differences in the risk of developing ADs between specific countries or ethnic groups living in the same area; and that type 1 diabetes is more common in northern European countries compared with southern countries; a similar pattern is suggested for multiple sclerosis, but with less area variation in rates. It was found that in the USA, blacks are at higher risk compared with whites with regard to systemic lupus erythematosus and scleroderma; and age at diagnosis is approximately 7 years younger among blacks with these diseases compared with whites. An increased risk of systemic lupus erythematosus has also been reported among Asian and AfroCaribbean immigrants in the UK; rheumatoid arthritis rates are similar among whites, blacks, and Hispanics.

Table 5 indicates that the higher prevalence of ADs mainly affects female individuals, with a ratio of 2:1 between the sexes, presenting a considerable similarity with a previous study [93] that states that women have a risk 2.7 times higher than men to acquire an $\mathrm{AD}$, manifesting in $78 \%$ of the cases in the female sex. Data analysis shows that the proportion of women and men suffering from ADs varies according to the disease, and the number of female individuals with Hashimoto's thyroiditis, rheumatoid arthritis, Graves' disease, and systemic lupus erythematosus presented statistical significance compared with males. The reasons for this inequality lie in the way that sex hormones influence the immune system, as women have higher corticosterone-cortisol concentrations than men and glucocorticoids suppress the production of sex hormones and the action of these hormones on the tissues, which are important mechanisms for the regulation of Th1 and Th2 cytokines in the inflammatory response to the development of ADs [94].

Most of the authors consulted [16,91,95-97] state that gender differences in the prevalence for ADs are most prominent in Sjögren's syndrome, systemic lupus erythematosus, Hashimoto's thyroiditis, Graves' disease, and scleroderma, in which $80 \%$ of patients are women. Regarding rheumatoid arthritis, multiple sclerosis, and myasthenia gravis, the proportion is lower, but $60 \%$ of the patients are still female. There is gender equivalence for ulcerative colitis and a preponderance of men over women for type 1 diabetes mellitus and ankylosing spondylitis.

Despite the acknowledgment that these studies conducted so far constitute a significant source of scientific information for public health, the state of the art of studies on the prevalence of ADs in the country can still be considered limited to meet the various demands for improving methods for their production and even compromising the composition of representative applied researches, especially in the area of clinical and environmental epidemiology.

Studies such as this can be useful for improving the quality of care and for better definition of causes, frequencies, types, severity, and communities, as well as for predicting and providing resources used and their appropriateness [98]. The results of this study allow improving the approach of patients as they are updated and monitored, stimulating public health measures.

\section{CONCLUSION}

In a region with broad social and regional inequality as this, changes in the approach to ADs are one of the greatest challenges of the current public health system. It is not only enough to detect the carriers, but also necessary to create conditions of early diagnosis to subsidize the effectiveness of the epidemiological surveys and the prevalence estimates to be made.

\section{CONFLICTS OF INTEREST}

The authors report no conflicts of interest. The authors alone are responsible for the content and writing of this article.

\section{AUTHOR CONTRIBUTIONS}

D.S.T.J. designed the study, developed methodology and data collection tools, conducted data analysis, and drafted the manuscript. C.M.O. contributed to the design of the study and data collection tools. E.M.A. supervised the research implementation, critically reviewed all aspects of the study, and assisted in drafting the manuscript. All the authors have approved the final manuscript. 


\section{ACKNOWLEDGMENTS}

The authors acknowledge with gratitude the support of the Regional Superintendent of Health of Teófilo Otoni, the municipal secretaries of health and the primary health care professionals of the Águas Formosas microregion, Minas Gerais, Brazil.

\section{ABBREVIATIONS}

ADs, autoimmune diseases; CI, confidence interval; kg, kilogram; $\mathrm{km}$, kilometer; $\mathrm{m}$, meter; $\mathrm{mg}$, milligram; Th, T helper cell, TX, Texas; UK, United Kingdom; USA, United States of America.

\section{REFERENCES}

[1] Davidson A, Diamond B. Autoimmune diseases. N Engl J Med 2001;345;340-50.

[2] Moroni I, Bianchi I, Lleo A. Geoepidemiology, gender and autoimmune disease. Autoimmun Rev 2012;11;A386-A92.

[3] Jacobson DL, Gange SJ, Rose NR, Graham NM. Epidemiology and estimated population burden of selected autoimmune diseases in the United States. Clin Immunol Immunopathol 1997;84;223-43.

[4] Eaton WW, Rose NR, Kalaydjian A, Pedersen MG, Mortensen PB. Epidemiology of autoimmune diseases in Denmark. J Autoimmun 2007;29;1-9.

[5] Walsh SJ, Rau LM. Autoimmune diseases: a leading cause of death among young and middle-aged women in the United States. Am J Public Health Res 2000;90;1463-6.

[6] Lerner A, Jeremias P, Matthias T. The World incidence and prevalence of autoimmune diseases is increasing. Int J Cel Dis 2015;3;151-5.

[7] Suhler EB, Lloyd MJ, Choi D, Rosenbaum JT, Austin DF. Incidence and prevalence of uveitis in Veterans Affairs Medical Centers of the Pacific Northwest. Am J Ophthalmol 2008;146;890.e8-6.e8.

[8] Ferraz MB. Tropical rheumatology. Epidemiology and community studies: Latin America. Baillière's Clin Rheumatol 1995;9;1-9.

[9] Sato EI, Bonfá ED, Costallat LTL, da Silva NA, Brenol JCT, Santiago MB, et al. Consenso brasileiro para o tratamento do lúpus eritematoso sistêmico (LES). Rev Bras Reumatol 2002;42;362-70.

[10] Senna ER, De Barros AL, Silva EO, Costa IF, Pereira LV, Ciconelli RM, et al. Prevalence of rheumatic diseases in Brazil: a study using the COPCORD approach. J Rheumatol 2004;31;594-7.

[11] Schoffen JPF, Prado IMM. Aspectos Epidemiológicos e Etiológicos da Doença de Crohn. Revista Saúde e Pesquisa 2011;4;73-80.

[12] Instituto Brasileiro de Geografia e Estatística. IBGE cidades. Available from: http://www.cidades.ibge.gov.br/xtras/uf.php? lang=\%5BAN\&coduf $=31$ \&search $=$ minas- gerais (accessed February 11, 2017).

[13] Ribeiro EM, Galizoni FM. Água, população rural e políticas de gestão: o caso do vale do Jequitinhonha, Minas Gerais. Revista Ambiente e Sociedade 2002;5;129-46.

[14] Sardu C, Cocco E, Mereu A, Massa R, Cuccu A, Marrosu MG. Population based study of 12 autoimmune diseases in Sardinia, Italy: prevalence and comorbidity. PLoS One 2012;7;1-5.
[15] Staii A, Mirocha S, Todorova-Koteva K, Glinberg S, Jaume JC. Hashimoto thyroiditis is more frequent than expected when diagnosed by cytology which uncovers a pre-clinical state. J Thyroid Res 2010;3;11-7.

[16] Cooper GS, Stroehla BC. The epidemiology of autoimmune diseases. Autoimmun Rev 2003;2;119-25.

[17] Bechelli LM, Haddad N, Pimenta WP, Pagnano PMG, Melchior Jr E, Fregnan RC, et al. Epidemiological survey of skin diseases in schoolchildren living in the Purus Valley (Acre State, Amazonia, Brazil). Dermatologica 1981;163;78-93.

[18] Marques-Neto JF, Gonçalves ET, Langen LFOB, Cunha MFL, Radominski S, Oliveira SM, et al. Multicentric study of the prevalence of adult rheumatoid arthritis in Brazilian population samples. Rev Bras Reumatol 1993;33:169-73.

[19] Spindler A, Bellomio V, Berman A, Lucero E, Baigorria M, Paz S, et al. Prevalence of rheumatoid arthritis in Tucumán, Argentina. J Rheumatol 2002;29;1166-70.

[20] Farber EM, Nall L. Epidemiology: Natural history and genetics. In: Roenigk HH, Maibach HI, editors. Psoriasis, 3rd ed. New York: Marcel Dekker; 1998, pp. 107-57.

[21] Raychaudhuri SP, Farber EM. The prevalence of psoriasis in the world. J Eur Acad Dermatol Venereol 2001;15;16-7.

[22] Laurberg P, Cerqueira C, Ovesen L, Rasmussen LB, Perrild H, Andersen S, et al. Iodine intake as a determinant of thyroid disorders in populations. Best Pract Res Clin Endocrinol Metab 2010;24;13-27.

[23] Alazraqui M, Mota E, Spinelli H. Sistemas de Información en Salud: de sistemas cerrados a la ciudadanía social. Un desafío en la reducción de desigualdades en la gestión local. Cad Saúde Pública 2006;22;2693-702.

[24] Barbosa DCM. Sistemas de informação em saúde: a percepção e a avaliação dos profissionais diretamente envolvidos na atenção básica de Ribeirão Preto/SP [dissertação]. Ribeirão Preto (SP): Universidade de São Paulo, 2006. Available from: https://www. teses.usp.br/teses/disponiveis/17/17139/tde-18092006155547/ publico/MsBarbosaDCM.pdf (accessed January 4, 2017).

[25] Silva AS, Laprega MR. Avaliação crítica do Sistema de Informação da Atenção Básica (SIAB) e de sua implantação na região de Ribeirão Preto, São Paulo, Brasil. Cad Saúde Pública 2005;21;1821-28.

[26] Alonso MD, Llorca J, Martinez-vazquez, F, Miranda-Filloy JA, Diaz de Teran T, Dierssen T, et al. Systemic lupus erythematosus in northwestern Spain: a 20-year epidemiologic study. Medicine 2011;90;350-8.

[27] López P, Mozo L, Gutiérrez C, Suárez A. Epidemiology of systemic lupus erythematosus in a northern Spanish population: gender and age influence on immunological features. Lupus 2003;12;860-5.

[28] Gamboa R, Medina M, Acevedo E, Pastor C, Cucho J, Gutiérrez C, et al. Prevalencia de enfermedades reumatológicas y discapacidad en una comunidad urbano-marginal: resultados del primer estudio Copcord en el Perú. Rev Peruana Reumatol 2009;15;40-6.

[29] Reyes-Llerena GA, Guibert-Toledano M, Penedo-Coello A, Pérez-Rodríguez A, Baez-Dueñas RM, Charnicharo-Vidal R, et al. Community-based study to estimate prevalence and burden of illness of rheumatic diseases in Cuba: a COPCORD study. J Clin Rheumatol 2009;15;51-5.

[30] Pimentel LCF. Perfil sociodemográfico e distribuição dos casos de Pênfigo Foliáceo Endêmico nas diferentes regiões do estado 
de Minas Gerais, no período de 2005 a 2006 / Luciana Cônsoli Fernandes Pimentel [dissertação], Belo Horizonte (MG): Universidade Federal de Minas Gerais; 2008, p. 75. Available from: http://www.bibliotecadigital.ufmg.br/dspace/bitstream/ handle/1843/ECJS7NAFRV/luciana_consoli_fernandes_pimentel.pdf? sequence=1 (accessed March 2, 2017).

[31] Sampaio SAP, Rivitti EA. Erupções vésico-bolhosas. In: Sampaio SAP, Rivitti EA, editors. Dermatologia. São Paulo: Artes Médicas; 1998, pp. 229-48.

[32] Aoki V, Millikan RC, Rivitti EA, Hans-Filho G, Eaton DP, Warren SJ, et al. Environmental risk factors in endemic pemphigus foliaceus (fogo selvagem). J Invest Derm Symp Proc 2004;9;34-40.

[33] Alabi GO, Akinsanya JB. Líquen planus em África tropical. Medicina Tropical e Geográfica 1981;33;143-7.

[34] Shiohara T, Kano Y. Lichen planus and lichenoid dermatoses. In: Bolognia JL, Jorizzo J, Rapini RP, editors. Dermatology. 2nd ed. New York: Mosby Elsevier; 2008, pp. 159-80.

[35] Habif TP. Dermatologia Clínica: Guia Colorido para Diagnóstico e Tratamento. $4^{\text {a }}$ ed. São Paulo: Artes Médicas; 2005.

[36] Schlosser BJ. Lichen planus and lichenoid reactions of the oral mucosa. Dermatol Ther 2010;23;251-67.

[37] Victoria CR, Sassak LY, Nunes HR. Incidence and prevalence rates of inflammatory bowel diseases, in midwestern of São Paulo State, Brazil. Arq Gastroenterol 2009;46;20-5.

[38] Souza MHLP, Troncon LEA, Rodrigues CM, Viana CFG, Onofre PHC, Monteiro RA, et al. Evolução da ocorrência (1980-1999) da doença de Crohn e da retocolite ulcerativa idiopática e análise das suas características clínicas em um hospital universitário do sudeste do Brasil. Arq Gastroenterol 2002;39;98-105.

[39] Hukuda S, Minami M, Saito T, Mitsui H, Matsui N, Komatsubara Y, et al. Spondyloarthropathies in Japan: nationwide questionnaire survey performed by the Japan Ankylosing Spondylitis Society. J Rheumatol 2001;28;554-9.

[40] Carbone LD, Cooper C, Michet CJ, Atkinson EJ, O'fallon WM, Melton LJ. Ankylosing spondylitis in Rochester, Minnesota, 1935-1989. Is the epidemiology changing?. Arthritis Rheum 1992;35;1476-82.

[41] Kaipiainen-Seppänen O, Aho K. Incidence of chronic inflammatory joint diseases in Finland in 1995. J Rheumatol 2000;27;94-100.

[42] Bakland G, Nossent HC, Gran JT. Incidence and prevalence of ankylosing spondylitis in Northern Norway. Arthritis Rheum 2005;53;850-5.

[43] Alamanos Y, Papadopoulos NG, Voulgari PV, Karakatsanis A, Siozos C, Drosos AA. Epidemiology of ankylosing spondylitis in northwest Greece, 1983-2002. Rheumatology (Oxford) 2004;43; 615-18.

[44] Zink A, Braun J, Listing J, Wollenhaupt J. Disability and handicap in rheumatoid arthritis and ankylosing spondylitis—results from the German rheumatological database. German Collaborative Arthritis Centers. J Rheumatol 2000;27;613-22.

[45] Sampaio-Barros PD, Bertolo MB, Kraemer MH, Neto JF, Samara AM. Primary ankylosing spondylitis: patterns of disease in a Brazilian population of 147 patients. J Rheumatol 2001;28;560-5.

[46] Valim V, Zandonade E, Pereira AM, de Brito Filho OH, Serrano EV, Musso C, et al. Primary Sjögren's syndrome prevalence in a major metropolitan area in Brazil. Rev Bras Reumatol 2013;53;24-34.
[47] Hochberg MC. The prevalence of dry eye, dry mouth, autoimmunity and primary Sjögren's syndrome in the general population [Abstract]. Arthritis Rheum 1996;39:S66.

[48] Zhang NZ, Shi CS, Yao QP, Pan GX, Wang LL, Wen ZX, et al. Prevalence of primary Sjögren's syndrome in China. J Rheumatol 1995;22;659-61.

[49] Thomas E, Hay EM, Hajeer A, Silman AJ. Sjögren's syndrome: a community-based study of prevalence and impact. Rev Bras Reumatol 1998;37;1069-76.

[50] Ferreira MLB, Machado MíM, Vilela ML, Guedes MJ, Ataíde L, Santos S, et al. Epidemiologia de 118 casos de esclerose múltipla com seguimento de 15 anos no centro de referência do hospital da restauração de Pernambuco. Arq Neuro-psiq 2004;62;1027-32.

[51] Ribeiro SBF, Maia DF, Ribeiro JB, Cardoso FAG, Silva C. Clinical and epidemiological profile of patients with multiple sclerosis in Uberaba, Minas Gerais, Brazil. Arq Neuro-psiq 2011;69;184-7.

[52] Lana-Peixoto MA, Frota ERC, Campos GB, Monteiro LP. Prevalência da esclerose múltipla em Belo Horizonte, Brasil. Arq Neuro-psiq 2012;70;102-7.

[53] Fragoso YD, Fiore APP. Description and characteristics of 81 patients attending the reference center for multiple sclerosis of the coastal region of the state of São Paulo - Brazil. Arq Neuropsiq 2005;63;741-44.

[54] Fragoso YD, Peres M. Prevalência de esclerose múltipla na cidade de Santos, SP. Rev Bras Epidemiol 2007;10;479-82.

[55] Lawrence RC, Helmick CG, Arnett FC, Deyo RA, Felson DT, Giannini EH, et al. Estimates of the prevalence of arthritis and selected musculoskeletal disorders in the United States. Arthritis Rheum 1998;41;778-99.

[56] Kermani TA, Warrington KJ. Polymyalgia rheumatica. Lancet 2013;381;63-72.

[57] Kermani TA, Warrington KJ. Advances and challenges in the diagnosis and treatment of polymyalgia rheumatica. Ther Adv Musculoskelet Dis 2014;6;8-19.

[58] Helliwell T, Lara Hider S, Mallen CD. Polymyalgia rheumatica: diagnosis, prescribing, and monitoring in general practice. $\mathrm{Br} \mathrm{J}$ Gen Pract 2013;63;e361-e6.

[59] Horimoto AMC, Matos ENN, Costa MRD, Takahashi F, Rezende MC, Kanomata LB, et al. Incidência e prevalência de esclerose sistêmica em Campo Grande, Estado de Mato Grosso do Sul, Brasil. Rev Bra Reumatol 2017;57;107-14.

[60] Chifflot H, Fautrel B, Sordet C, Chatelus E, Sibilia J. Incidence and prevalence of systemic sclerosis: a systematic literature review. Semin Arthritis Rheum 2008;37;223-35.

[61] Barnes J, Mayes MD. Epidemiology of systemic sclerosis: incidence, prevalence, survival, risk factors, malignancy, and environmental triggers. Curr Opin Rheumatol 2012;24;165-70.

[62] Goldenstein-Schainberg C, Saad CGS, Gonçalves CR. Espondiloartrites. In: Shinko SK. (org.). Reumatologia. São Paulo: Editora Atheneu; 2010, pp. 137-53.

[63] Ritchlin CT, Qureshi AA, de Vlam K, Pitzalis C, Helliwell PS, Mease PJ, et al. Biomarkers in psoriasis and psoriatic arthritis: GRAPPA 2008. J Rheumatol 2010;37;462-67.

[64] Gladman DD, Mease PJ, Choy EH, Ritchlin CT, Perdok RJ, Sasso EH. Risk factors for radiographic progression in psoriatic arthritis: subanalysis of the randomized controlled trial ADEPT. Arthritis Res Ther 2010;12;R113.

[65] Safavi K. Prevalence of alopecia areata in the First National Health and Nutrition Examination Survey. Arch Dermatol 1992;128;702. 
[66] Laureti S, Vecchi L, Santeusanio F, Falorni A. Is the prevalence of Addison's disease underestimated? J Clin Endocrinol Metab $1999 ; 84 ; 1762$.

[67] Cervera R, Piette JC, Font J, Khamashta MA, Shoenfeld Y, Camps MT, et al. Antiphospholipid syndrome: clinical and immunologic manifestations and patterns of disease expression in a cohort of 1,000 patients. Arthritis Rheum 2002;46;1019-27.

[68] Rodrigo-Sáez L, Fuentes-Álvarez D, Pérez-Martínez I, AlvarezMieres N, Niño-García P, de-Francisco-García R, et al. Differences between pediatric and adult celiac disease. Rev Esp Enferm Dig 2011;103;238-44.

[69] Victoria CR, Sassak LY, Nunes HR. Incidence and prevalence rates of inflammatory bowel diseases, in midwestern of São Paulo State, Brazil. Arq Gastroenterol 2009;46;20-5.

[70] Osserman KE, Genkins G. Studies in myasthenia gravis: review of a twenty-year experience in over 1200 patients. Mt Sinai J Med 1971;38;497-537.

[71] Rosa J, Garrot LF, Navarta DA, Saucedo C, Scolnik M, Bedran Z, et al. Incidence and prevalence of polymyositis and dermatomyositis in a health management organization in Buenos Aires. J Clin Rheumatol 2013;19;303-7.

[72] Terrell DR, Beebe LA, Neas BR, Vesely SK, Segal JB, George JN. Prevalence of primary immune thrombocytopenia in Oklahoma. Am J Hematol 2012;87;848-52.

[73] Moreno GA, Ferrando J. Alopecia areata. Med Cutan Ibero Lat Am 2000;28;294-312.

[74] Rivitti EA. Alopecia areata: revisão e atualização. An Bras Dermatol 2005;80;57-68.

[75] Slobodin G, Hussein A, Rozenbaum M, Rosner I. The emergency room in systemic rheumatic diseases. Emerg Med J 2006;23;667-71.

[76] Spina GS. Doença reumática: negligenciada, mas ainda presente e mortal. Rev Med 2008;87;128-41.

[77] Dourado ME, Félix RH, da Silva WK, Queiroz JW, Jeronimo SM. Clinical characteristics of Guillain-Barré syndrome in a tropical country: a Brazilian experience. Acta Neurol Scand 2012;125;47-53.

[78] Dias-Tosta E, Kückelhaus CS. Guillain Barré syndrome in a population less than 15 years old in Brazil. Arq Neuropsiquiatr 2002;60;367-73.

[79] Rocha MS, Brucki SM, Carvalho AA, Lima UW. Epidemiologic features of Guillain-Barré syndrome in São Paulo, Brazil. Arq Neuropsiquiatr 2004;62;33-7.

[80] Ferraz MB. Tropical rheumatology. Epidemiology and community studies: Latin America. Baillieres Clin Rheumatol 1995;9;1-9.

[81] Granieri E, Economou NT, De Gennaro R, Tola MR, Caniatti L, Govoni V, et al. Multiple sclerosis in the province of Ferrara: evidence for an increasing trend. J Neurol 2007;254;1642-48.

[82] Svenson LW, Warren S, Warren KG, Metz LM, Patten SB, Schopflocher DP. Prevalence of multiple sclerosis in First Nations people of Alberta. Can J Neurol Sci 2007;34;175-80.

[83] Felson DT. Comparing the prevalence of rheumatic diseases in China with the rest of the world. Arthritis Res Ther 2008;10;106.
[84] de Carvalho FM, da Costa MC, da Silva TCD. Doenças reumáticas no Brasil: revisão de estudos epidemiológicos. Revista Digital, Buenos Aires, Ano 18, no 184, 2013. Available from: http://www. efdeportes.com/efd184/doencas-reumaticas-no-brasil-revisao. htm (accessed January 3, 2017).

[85] Marrie RA, Reider N, Cohen J, Stuve O, Sorensen PS, Cutter G, et al. A systematic review of the incidence and prevalence of autoimmune disease in multiple sclerosis. Mult Scler 2015;21;282-93.

[86] Varadkar S, Bien CG, Kruse CA, Jensen FE, Bauer J, Pardo CA, et al. Rasmussen's encephalitis: clinical features, pathobiology, and treatment advances. Lancet Neurol 2014;13;195-205.

[87] Rivera JA. Lymphocytic hypophysitis: disease spectrum and approach to diagnosis and therapy. Pituitary 2006;9;35-45.

[88] Lima AKSM, Garcia CAA, Faria MAR, Uchoa UBC. Síndrome de Cogan: achados oculares em um caso da forma atípica. Arq Bras Oftalmol 2006;69;937-40.

[89] Faria LC, Ferrari MLA, Cunha AS. Aspectos clínicos da doença de Crohn em um centro de referência para doenças intestinais. GED Gastroenterol Endosc Dig 2004;23;151-64.

[90] Anaya JM, Shoenfeld Y, Rojas-Villarraga A, Levy RA, Cervera R, editors. Autoimmunity: From Bench to Bedside [Internet]. Bogota (Colombia): El Rosario University Press; 2013. Available from: https://www.ncbi.nlm.nih.gov/books/NBK459433/ (accessed March 4, 2017).

[91] de Souza MM, Belasco AGS, Aguilar-Nascimento JE. Perfil epidemiológico dos pacientes portadores de doença inflamatória intestinal do estado de Mato Grosso. Rev Bra Coloproctol 2008;28;324-28.

[92] Schoels M, Wong J, Scott DL, Zink A, Richards P, Landewé R, et al. Economic aspects of treatment options in rheumatoid arthritis: a systematic literature review informing the EULAR recommendations for the management of rheumatoid arthritis. Ann Rheum Dis 2010;69;995-1003.

[93] Quintero OL, Amador-Patarroyo MJ, Montoya-Ortiz G, RojasVillarraga A, Anaya JM. Autoimmune disease and gender: plausible mechanisms for the female predominance of autoimmunity. J Autoimmun 2012;38;J109-J19.

[94] Rotondi M, Falorni A, De Bellis A, Laureti S, Ferruzzi P, Romagnani P, et al. Elevated serum interferon- $\gamma$-inducible chemokine-10/cxc chemokine ligand-10 in autoimmune primary adrenal insufficiency and in vitro expression in human adrenal cells primary cultures after stimulation with proinflammatory cytokines. J Clin Endocrinol Metab 2005;90;2357-63.

[95] Whitacre CC. Sex differences in autoimmune disease. Nat Immunol 2001;2:777-80.

[96] National Institutes of Health. Autoimmune Diseases Coordinating Committee: Autoimmune Diseases Research Plan. National Institutes of Health: USA; 2005.

[97] Sampaio-Barros PD. Epidemiology of spondyloarthritis in Brazil. Am J Med Sci 2011;341;287-88.

[98] Gomes MM, Li LM, Nicole-Carvalho V. Estudos Epidemiológicos. J Epilepsy Clin Neurophysiol 2005;11;16-9. 